\title{
THE EFFECT OF WEST QURNA OILFIELD ON THE PART OF EUPHRATES RIVER, NORTHERN BASRA GOVERNORATE, IRAQ: GEOMORPHIC AND STRUCTURAL GEOLOGY INTEGRATED ANALYSIS
}

\author{
${ }^{1}$ Aymen Adil Lazim*, ${ }^{2}$ Meelad Ali Hussein and ${ }^{3}$ Huda Fannoosh Khazaal \\ ${ }^{1}$ Geoscience Department, Zubair Field Operation Division, Basra Oil Company \\ ${ }^{2}$ Faculty of Marine Science, University of Basra \\ ${ }^{3}$ Studies, Planning \& Follow Division, Basra Oil Company \\ *E-mail: aymanalkendi@gmail.com
}

Received: 1 June 2019; accepted: 3 January 2020

\begin{abstract}
The study utilized geomorphic and structural geology analysis integrated analysis to understand the effect of West Qurna Oilfield on the part of the Euphrates river route, whether it's related to neotectonic activity or it's a natural phenomenon. The Euphrates River Drainage Basin is located in the northern part of the Basra in the south of the Mesopotamian. The channel of the river is mostly straight and characterized by large loops. The channel sinuosity of this river system is analyzed in order to draw conclusions on the neotectonic activity of the region. The original status of the river thalweg was digitized from recent satellite images using the new Landsat 8 Scenes. Sinuosities at different sample section lengths were computed in a GIS software environment ArcGIS 10, providing the so-called 'sinuosity spectra' for each point of the analyzed using a moving-window method and different window sizes channels. High sinuosity sections were correlated to geological subsurface structures of West Qurna Oilfield identified, indicating their neotectonic activity. A structural analysis performed to identify its type, origin and to find its relevance to main regional tectonic events. The geometric analysis detects that the bending fold mechanism (vertical force) could responsible for form West Qurna Oilfield. Thus, thinning features associated with the Oilfield. This mechanism could be connected with the growth of salt structure of Hormuz Salt below it as confirmed by negative residual anomaly associated with West Qurna Oilfield.
\end{abstract}

Keywords: Structural analysis; Neotectonic movement; River Pattern, Sinuosity index 


\section{INTRODUCTION}

The alluvial rivers are one of the landforms that changed the earth's surface through the processes of erosion and deposition. It was among the significant features used as indicators that it reflects the effect of the neotectonic movement (Burnett and Schumm, 1983; Ouchi, 1985). These movements have a direct influence on the valley floor slope (Holbrook and Schumm, 1999). Therefore, the channel pattern, aggradation and degradation of the rivers changed answering to these movements (Schumm et al., 2002). The aims of this paper are to (1): analysis of river pattern for the Euphrates river near West-Qurna Oilfield and their relationship with the evolution of subsurface structures and neotectonic movements, (2): geological analysis (Geometric, Genetic) for the subsurface structures in this area. The West-Qurna Oilfield located about $65 \mathrm{~km}$ northwest of Basra city southern Iraq, between latitude $\left(30^{\circ} 53^{\prime} 07^{\prime \prime}-31^{\circ} 3^{\prime} 16^{\prime \prime} \mathrm{N}\right)$ and longitude $\left(47^{\circ} 17^{\prime} 27^{\prime \prime}-47^{\circ}\right.$ $22^{\prime} 24 "$ E), north of Rumaila oilfield.

\section{GEOLOGICAL SETTING}

Geographically the study area locates between the latitudes $\left(31^{\circ} 0^{\prime} 47.0524^{\prime \prime}-30^{\circ} 53^{\prime} 30.6918^{\prime \prime} \mathrm{N}\right)$ and Longitudes ( $47^{\circ} 9^{\prime} 54.2129^{\prime \prime}-47^{\circ} 27^{\prime} 6.9785^{\prime \prime}$ E). It represents by Euphrates River and part of the Hammar Marshes within Basrah Governorate. It is a flat surface where the elevation between (0$16 \mathrm{~m}$ ) above sea level (Fig. 1).

Tectonically, the area is belonging to the tectonic divisions (Mesopotamian Zone, Zubair Subzone). These structures are an extension of the Unstable Shelf of the Arabian Platform (Buday and Jassim, 1987; Al-Khadhimi et al., 1996). According to (Numan 1997\&2000) it lies in sagged basin within the Mesopotamian Zone of the qusiplatform foreland belt of the Arabian Plate.

Zubair Subzone bounded by basement faults, which are Takhadid-Qurna Transversal fault from north and southern boundary, is Al-Batin fault (Jassim and Goff, 2006). This region characterized by a very thick sedimentary cover and anticlinal subsurface structures separated synclinal subsurface structures. These structures associated with negative gravity anomalies that evidenced the presence of the deep-seated Infracambrian salt rocks (Karim, 1989; Karim, 1993; Jassim and Goff, 2006; Karim et al., 2010). The tectonic development of the Zubair Subzone affected or controlled by three main tectonic sources: The Alpine Orogeny, basement faults, salt tectonics, (Al-Sakini, 1986).

Geologically, the area is characterized by thick Quaternary sediments belong to the Pleistocene and Holocene Period. It is represented by floodplain sediments of lower Mesopotamian 
plain exemplified by the floodplain of the Euphrates and Tigris rivers, (Yacoub, 1992). The sediments are grey colored and fine contain organic material and particles of Mollusca and Ostracoda varied with carbonate, clay, silt, and sand. Hammar Formation underlaid these sediments were marine and lacustrine sediments, belongs to early Holocene (Yacoub 1992\&2011). The oil is present in many formations, which are from bottom to top: Sa adi, Khasib, Mishrif/Rumaila, Mauddud (Late Cretaceous), Maudud and Nahr Umr formations (Middle Cretaceous), Zubair, Ratawi and Yamama formations (Early Cretaceous), Sulay, Gotnia, (Upper Jurassic) (Grabowski, 2014).

\section{MATERIALS AND METHODS}

\section{Geomorphic Analysis}

The geomorphic analysis by the sinuosity index performed using satellite imagery of the Landsat 8 Operational Land Imager (OLI) (Path166, Row38, 39) and DEM ALOS_DSM show the topography provided form the (USGS, JAXA) websites with help of the GIS Environment. The Arc-Toolbox package is used for pre-image processing and post-image processing for creating suitable raster. It includes processing such mosaic different scenes, color composite bands, and unsupervised iso-class classification for extracting the shapefile of the river. Various shapefiles (Points, Polylines, and Polygons) were created and projected into a world geodetic system (WGS 84 zone 38N), using the Arc-Catalog package in ArcGIS Environment.

Shapefiles were created of the river reach. These shapefiles concern with thalweg line (curved channel) and straight line between precise vertices on the river based on the window size used in this study (3,4\&5) Km (Fig.2). New shapefiles for sinuosity index were created and added new fields contain the river segments, then complete calculations by the (Calculate Geometry, Field Calculator) utilized the attribute table. Sinuosity index classified into classes based on Schumm (1963). It may show in ArcGIS symbology in different colors and make a sinuosity spectrum. The sinuosity is a quantitative parameter has several definitions by many investigators who investigated their researches with the subject of fluvial geomorphology (Leopold and Wolman, 1957; Schumm, 1963; Langbein et al., 1966; Mueller, 1968; Schumm and Khan, 1972). Sinuosity as a simple concept may define as the ratio of the channel length to the valley length. However, the distance on such a stream can be measured between two points on the stream along the channel (thalweg) divided by the straight-line distance between two points. It is called the sinuosity ratio (Schumm, 1963; Brice, 1984; Ebisemiju, 1994), that is determined whether a channel is straight or meandering (Aswathy, et al., 2008). The sinuosity index used in the formula below: 
S.I. $=\frac{\text { the length of thalweg along the river }}{\text { the length of valley (distance of the two end points in straight line })}$

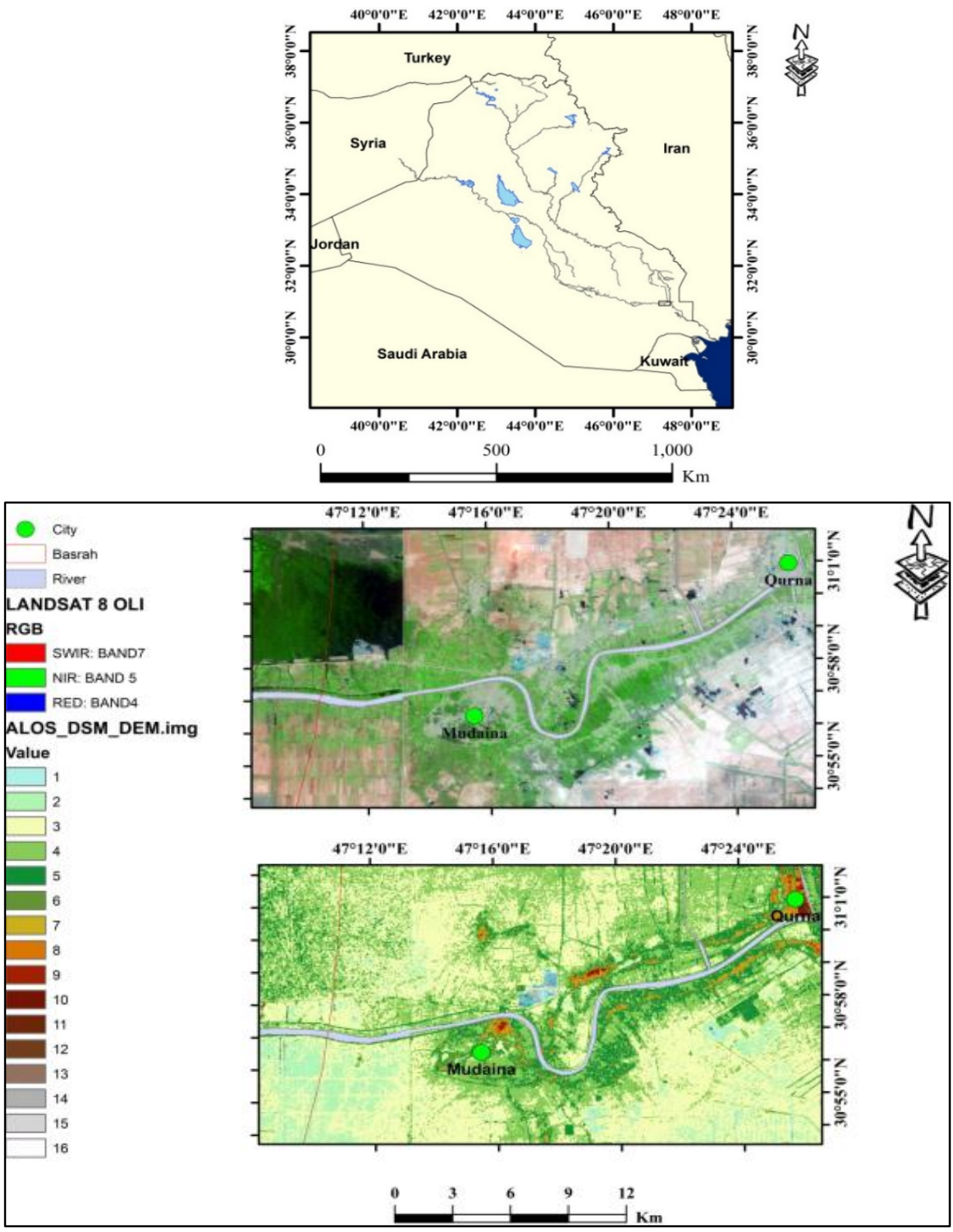

Fig. 1. Location map of the study area A. Landsat 8 OLI, B. ALOS_DSM DEM elevation in meter (a.s.l.) 
Numerous studies pointed out that the planform of alluvial rivers is controlled by several factors: discharge, sediment load, and tectonic effects (Schumm, 1963; Schumm and Khan, 1972; Adams, 1980; Ouchi, 1985; Holbrook and Schumm, 1999; Schumm, et al., 2002). The tectonic movements have a direct effect on the gradient or slope of the river basin. Therefore, the smallest changes in the topography affect the sinuosity of low gradient rivers (Holbrook and Schumm 1999) that make the sinuosity as an indicator to slope variance (Timár, 2003).

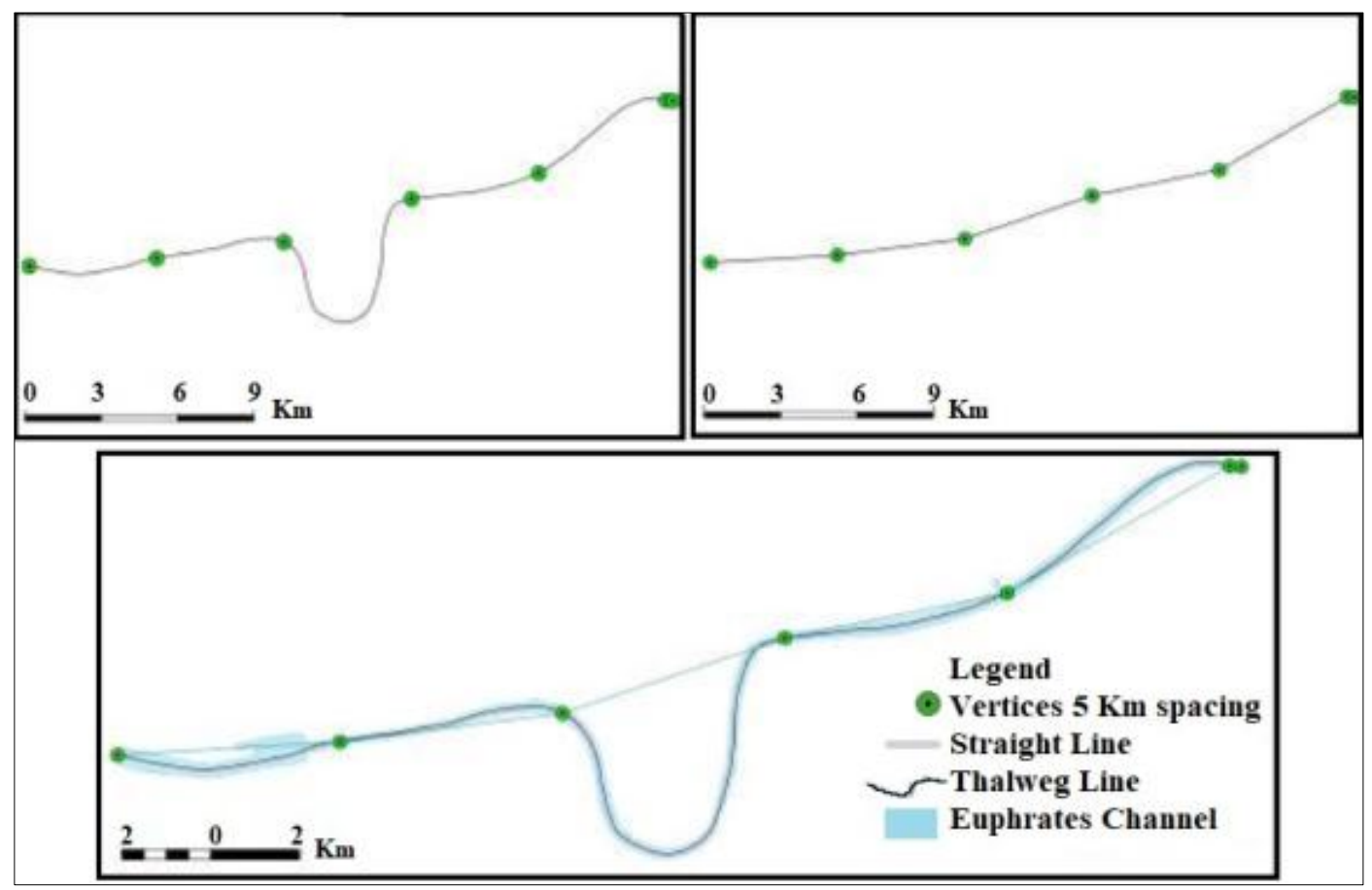

Fig. 2. River sinuosity index calculation steps based on the definition in the context

\section{Structural Geology Analysis}

\section{Geometric Analysis}

An updated geological model (static model) of the West Qurna Oilfield used to construct depth and thickness contour maps via Petrel software ver. 2016 with scale 1:125000. All well data (locations, tops) and river reach imported in Petrel software as a readable GIS shapefile format (Point, Polygon). In addition, the stereographic projection utilized to analyze orientation of lines and planes and determine the structural geological attitude; interlimb angle, hinge line or fold axis, and axial surface (Fig.3) (Tabel.1) through Stereonet software ver. 9.

The dip and strike [clockwise] calculated from the depth contour map (Fig.4) and thickness variation from drilling data (well tops) of Hartha, Mishrif, and Nahr Umr formations. According to the essential parameters of the fold, West Qurna Oilfield classified depending on (1) Fold facing, 
(2) Fold orientation (dip of axial surface, plunge of hinge line, and symmetry of fold), (3) Fold shape in profile plane (interlimb angle and variation in thickness).

Table 1. Stereographic projection results based on geometric analysis of Nahr Umr, Mishrif, and Hartha formations, West-Qurna Oilfield

\begin{tabular}{|c|c|c|c|c|c|}
\hline Formation & $\begin{array}{c}\text { Western } \\
\text { Limb }\end{array}$ & $\begin{array}{c}\text { Eastern } \\
\text { Limb }\end{array}$ & Interlimb Angle & $\begin{array}{c}\text { Axial } \\
\text { surface }\end{array}$ & $\begin{array}{c}\text { Plunge of } \\
\text { Hinge line }\end{array}$ \\
\hline Hartha & $5^{\circ} / 168^{\circ}$ & $1.5^{\circ} / 348^{\circ}$ & $173.5^{\circ}$ & $88.2^{\circ} / 348^{\circ}$ & 1 \\
\hline Mishrif & $2.4^{\circ} / 178^{\circ}$ & $1.6^{\circ} / 358^{\circ}$ & $176^{\circ}$ & $89.6^{\circ} / 358^{\circ}$ & 1.3 \\
\hline Nahr Umr & $5^{\circ} / 176^{\circ}$ & $3.8^{\circ} / 354^{\circ}$ & $171.2^{\circ}$ & $89.4^{\circ} / 356^{\circ}$ & 1.9 \\
\hline
\end{tabular}

1- Fold Facing: According to the direction of a closure, which is obtained from the direction of axial surface direction, the cross section and the values of dip and strike of Hartha, Mishrif, and Nahr Umr formations are an anticline structure (Table 1).

2- Fold Orientation: it includes two parameters:

The dip of axial surface: An axial surface defined as a surface that connects fold hinge lines (Groshong, 2006). Stereographic projection determined the attitude of the axial surface of Hartha, Mishrif, and Nahr Umr formations as shown in (Tabel.1), therefore West Qurna Oilfield structure classified as upright fold according to the value of axial surface (Table 1).

The plunge of the hinge line (fold axis): Hinge line is a line included the maximum curvature on the surface of a layer (Groshong, 2006). However, it represented as a straight line called Fold axis (Fossen, 2016). Hartha, Mishrif and Nahr Umr formations classified as a horizontal fold or nonplunged because the degree of the hinge line plunge is less than $10^{\circ}$ (Fossen, 2016) (Table 1).

Symmetry of the fold: West Qurna Oilfield considers as an asymmetrical structure because the dips of western limbs are more than eastern limb for Hartha, Mishrif, and Nahr Umr formations are (Table 1). 


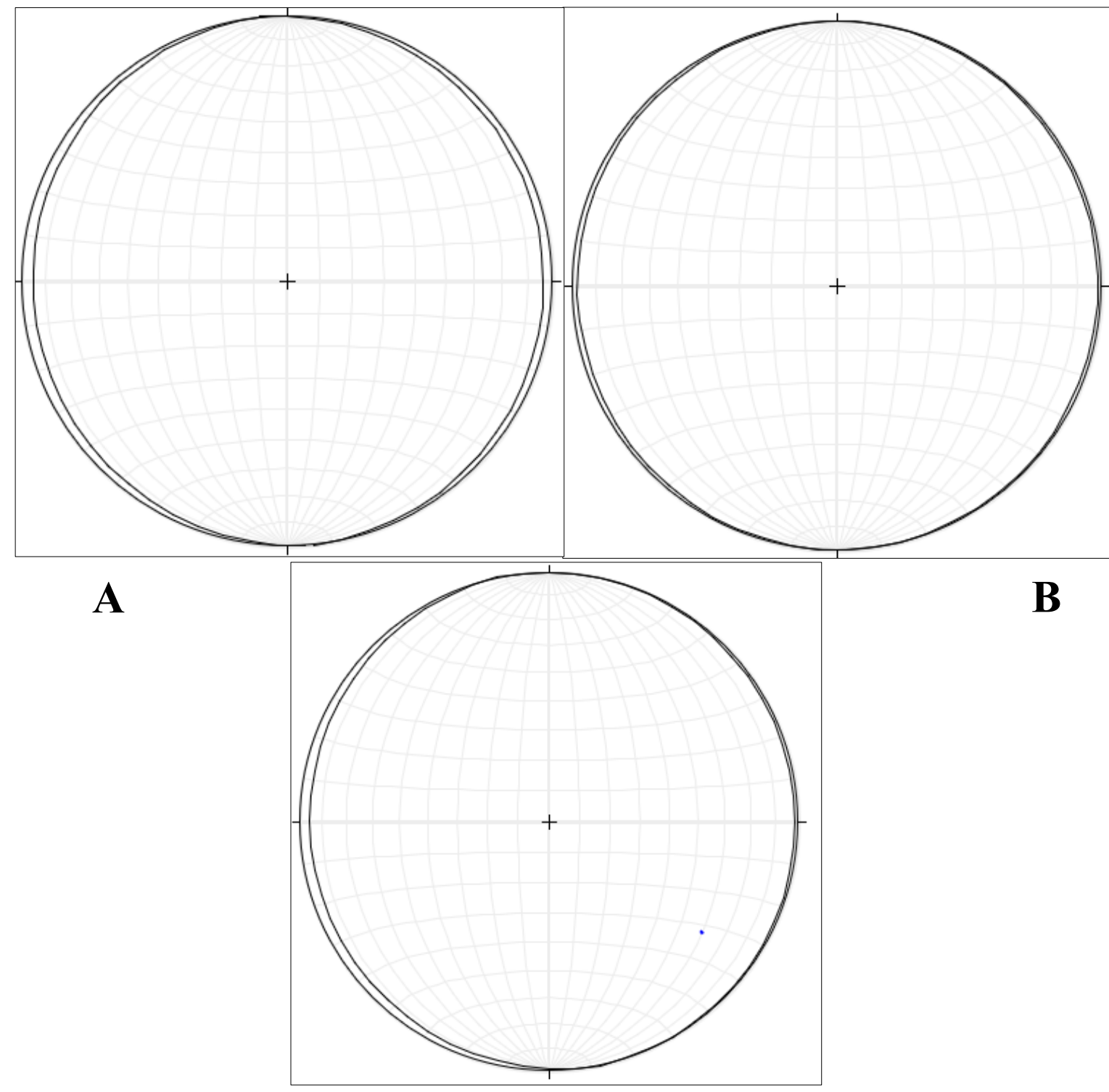

C

Fig. 3. Equal area stereographic plots of the three formations A, B, C Nahr Umr, Mishrif, and Hartha, respectively, which drawn according to the analysis of structural geology attitudes 

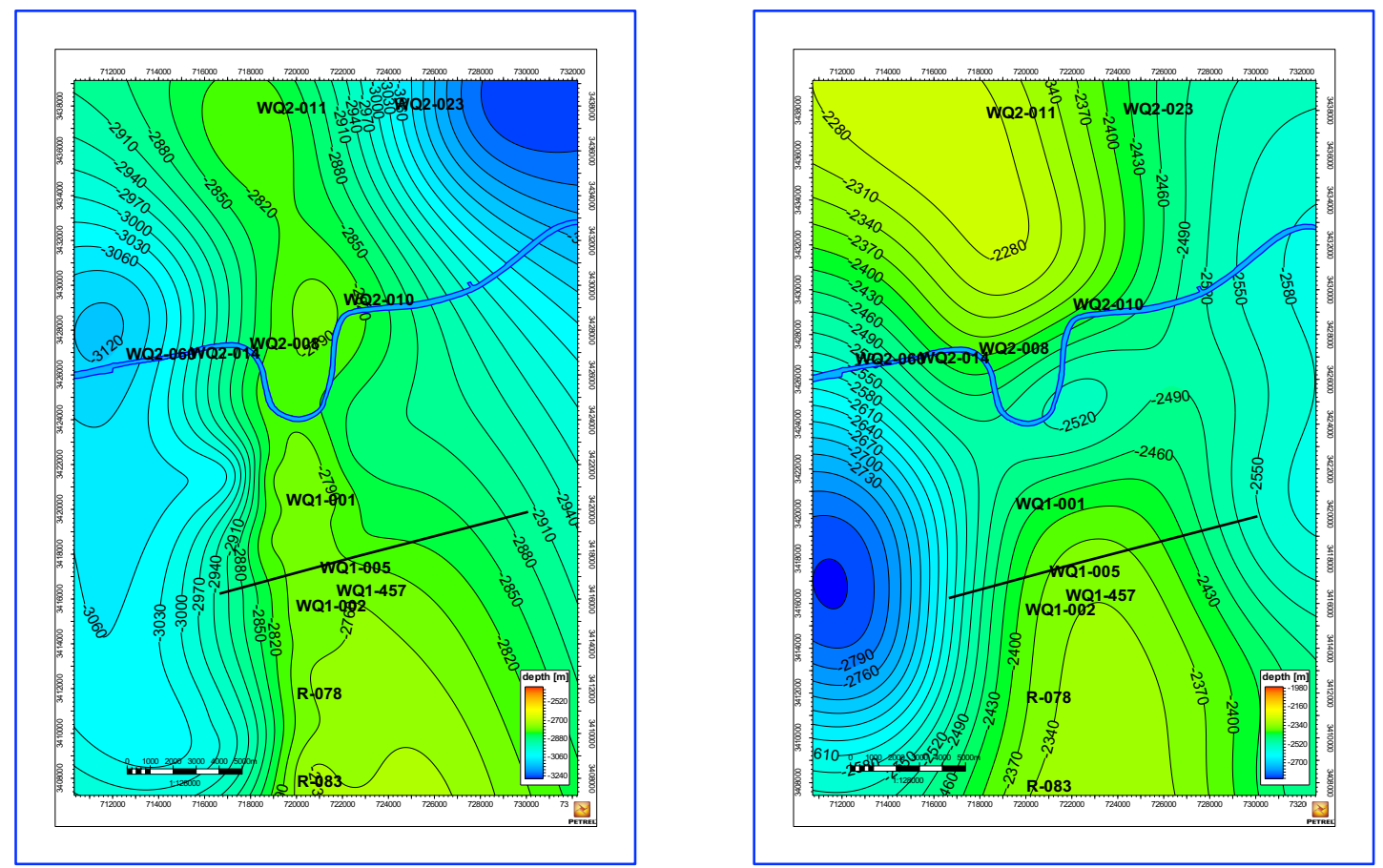

A

B

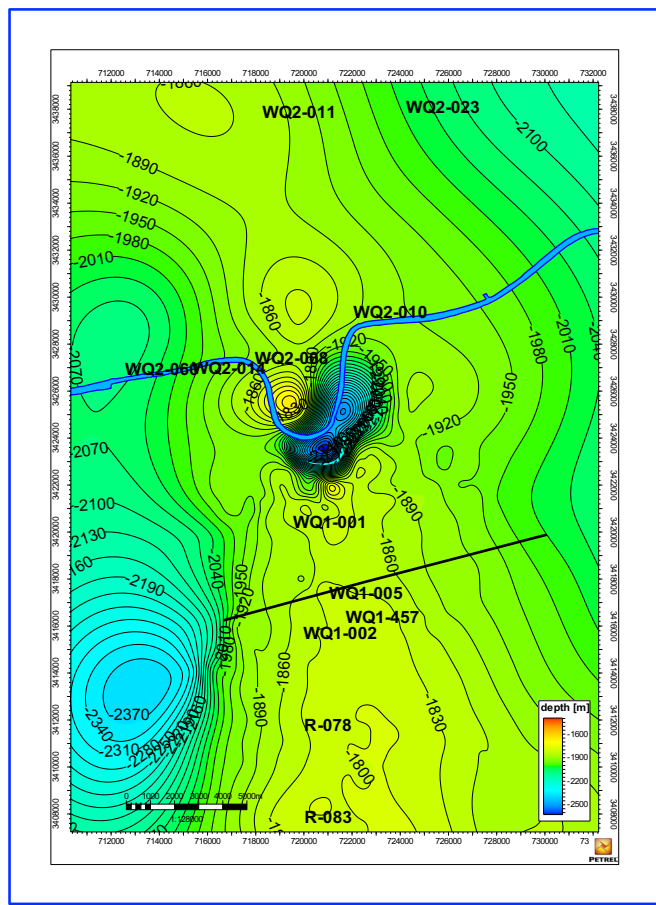

C

Fig. 4. Structural subsurface maps of the three formations A, B, C Nahr Umr, Mishrif, and Hartha respectively - West-Qurna Oilfield with measurement section (black line)

The fold classification that uses the profile plane of a fold uses two parameters; the interlimb angle and variation in thickness (Van der Pluijm and Marshak, 2004). 
Interlimb Angle: The angle between the limbs of a fold is called the interlimb angle (Fleuty, 1964). The interlimb angle of Hartha, Mishrif, and Nahr Umr Formation are $173.5^{\circ}, 176^{\circ}$ and $171.2^{\circ}$, respectively, therefore West Qurna Oilfield classified as gentle fold.

The variation in thickness: The crest's thickness of Hartha, Mishrif, and Nahr Umr Formations are less than its limb thickness. Therefore, these formations classified as supratenous fold and this type of fold formed when the sedimentation coincides with folding (Bhattacharya, 2005). This variation may relate to the bending folding mechanism, which is may form the Qurna Oilfield structure.

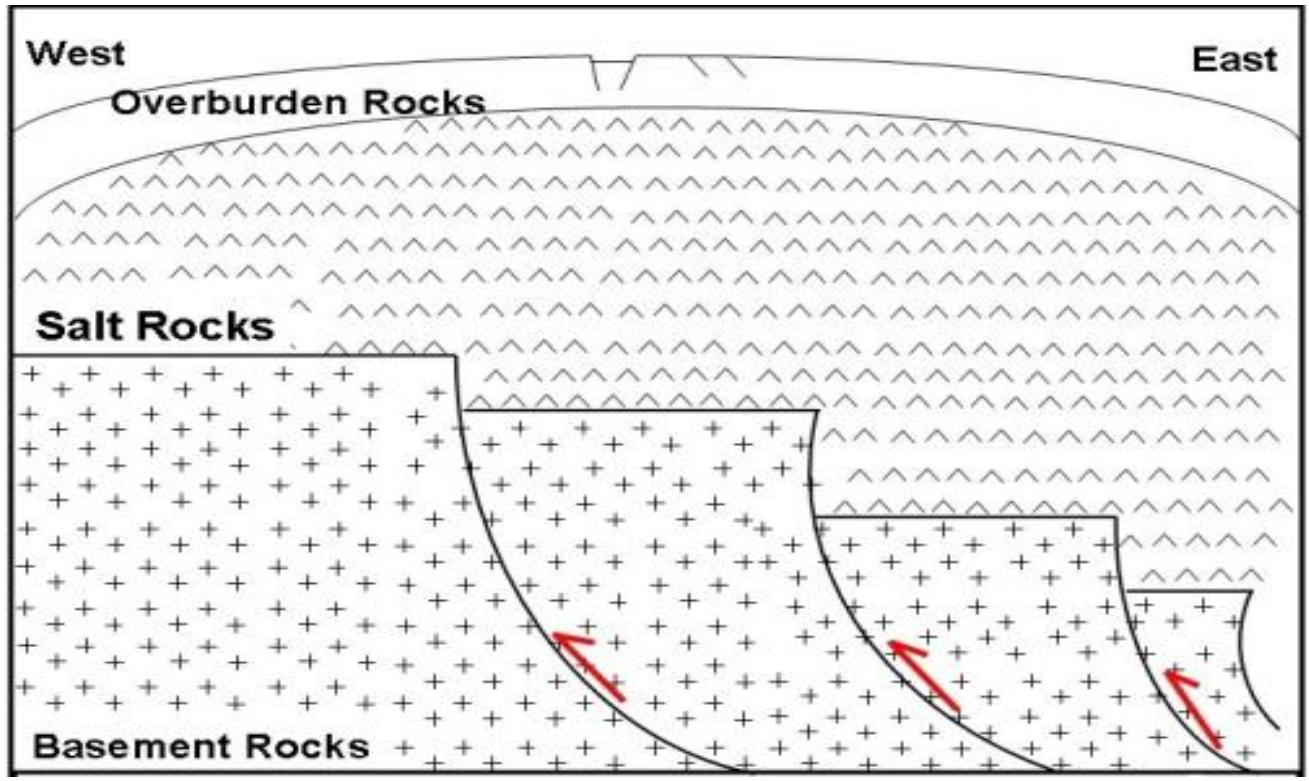

Fig. 5. Tectonic model for oil fields in the south of Iraq at compression phase (Upper Jurassic till recent) (Lazim, 2011)

\section{Genetic Analysis}

Geophysical surveys of southern Iraq indicated that the association of negative gravity could be because of deep-seated salt beds of Infra-Cambrian salt beds, while, the positive gravity referred to basement uplift (Karim 1989, 1993; Jassim and Goff 2006; Karim et. al, 2010). Karim et. al. (2010) referred to negative anomaly associated with north West Qurna Oilfield, this may relate to Infra-Cambrian salt structures (Hormuz salt structure). As result, three combined main forces worked together to produce subsurface anticline structures in southern Iraq included West Qurna Oilfield, these are tectonic Movements, reactivated basement faults, and Hormuz salt structures (Karim, 1989\&1993; Al-Sakini, 1993; Numan, 1997; Jassim and Goff, 2006) shown in tectonic model (Fig. 5) (Lazim, 2011). The study noticed that there is no saddle between West Qurna 
Oilfield and North Rumaila Oilfield, but there is a shallow saddle inside West Qurna Oilfield that may responsible for the change in Euphrates River route.

\section{RESULTS AND DISCUSSION}

\section{Geomorphic Analysis (S.I.)}

Sinuosity indices were computed according to the definition of Schumm (1963). Then it has been classed into classes agreeing to the classification of Schumm (1986) (Table 2). The studied segments of the Euphrates River start from the border of Basra Governorate Mudaina city, and ends to the confluence of Tigris and Euphrates rivers at Qurna with length of about $32 \mathrm{Km}$, and the sinuosity spectrum was showed for each section (Fig. 6)

Table 2. Sinuosity index values of Euphrates river course $4 \mathrm{Km}$ window size derived from S.I. method in context

\begin{tabular}{|c|c|c|c|c|c|}
\hline $\begin{array}{c}\text { Segment } \\
\text { No. }\end{array}$ & $\begin{array}{c}\text { Sinuosity } \\
\text { Value }\end{array}$ & $\begin{array}{c}\text { Sinuosity } \\
\text { Class }\end{array}$ & $\begin{array}{c}\text { River } \\
\text { Morphology }\end{array}$ & Frequency & Percentage\% \\
\hline 1 & 1.02 & $1-1.05$ & Straight & 5 & 62.5 \\
\hline 2 & 1.01 & $1.06-1.3$ & Low sinuous & 2 & 25 \\
\hline 3 & 1.24 & $1.31-3$ & Meandering & 1 & 12.5 \\
\hline 4 & 1.42 & & & & \\
\hline 5 & 1.13 & & & & \\
\hline 6 & 1.02 & & & & \\
\hline 7 & 1.03 & & & & \\
\hline 8 & 1 & & & & Sum $=100 \%$ \\
\hline
\end{tabular}

The sinuosity index computed using different window sizes (3, 4 and 5) $\mathrm{Km}$. However, the sinuosity indices are scale sensitive (Zámolyi et al., 2010) but it is valuable when it exhibits the same morphological changes at several window-sizes (Petrovszki and Timár 2010). It generally depends on the planform of the river (Meander) where it compound bends or single bends for large or small window size respectively, According to Gasparini (2016) (pers.comm, 5 June 2016). The morphological feature of Euphrates River is single bend, so the small window size is suitable for the Euphrates river reach in this study. This is compatible with the results of the structural analysis, where it displayed the saddle in the West-Qurna Field (Fig.4.

Euphrates River, which runs northwestern of Basra city, exhibits markedly straight pattern where all studied segments have sinuosity index equal to (1) (Table 2) at different window sizes. At Distance approximately $(8-10 \mathrm{~km})$ from the Euphrates River appears sudden change in sinuosity 
and in river morphology from straight to the sinuous pattern in window size $3,4 \mathrm{Km}$, and straight to the meandering pattern in window size $5 \mathrm{~km}$. This region is the location of the West-Qurna Oil filed. More studies pointed out that the Euphrates River influenced by the West-Qurna subsurface structure (Al-Sakini, 1993; Jassim and Goff, 2006).

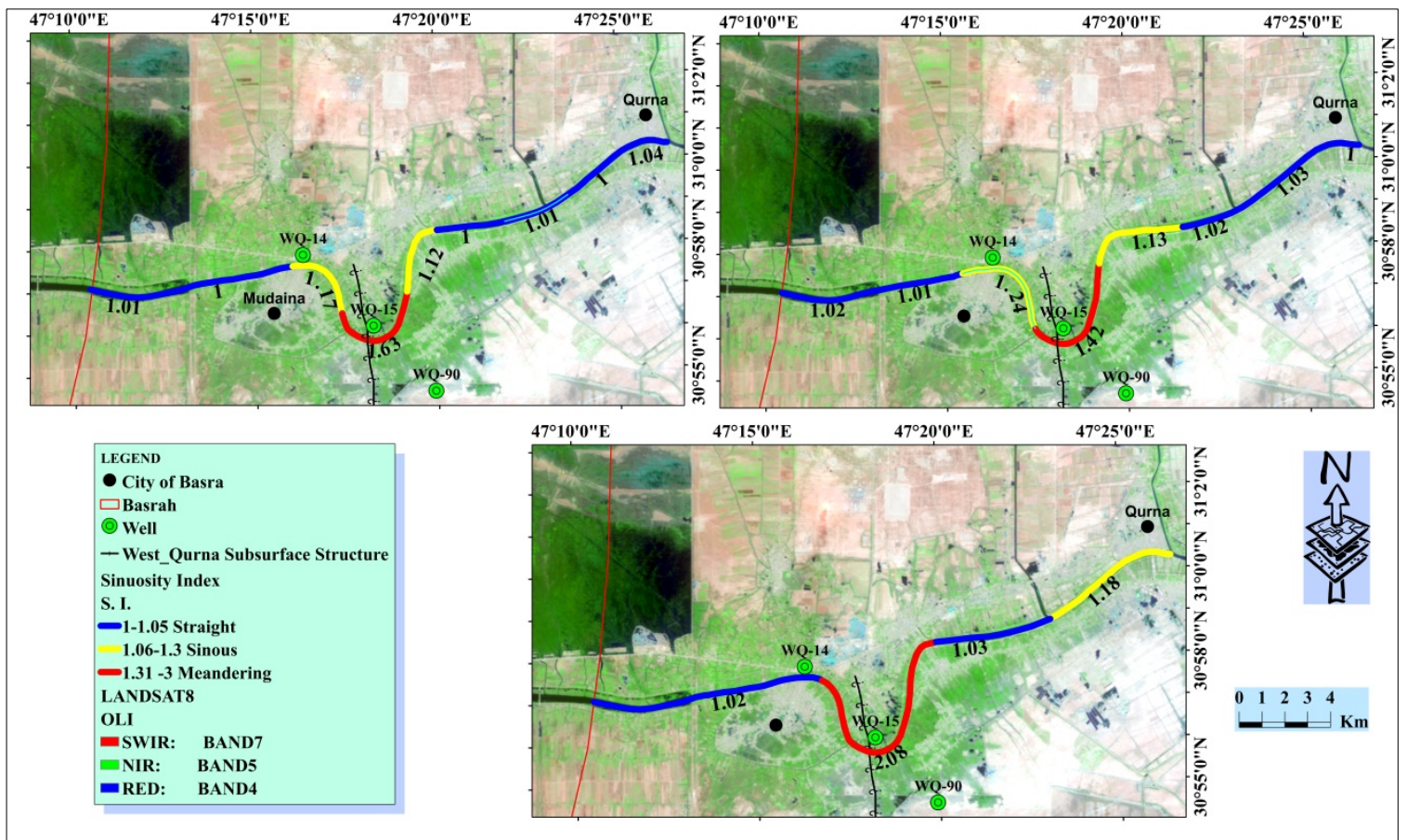

Fig. 6. Sinuosity index for Euphrates River with different window sizes 3, 4, $5 \mathrm{~km}$. Sinuosity index for Euphrates River with different window size 3, 4, $5 \mathrm{~km}$ based on the S.I. the result is shown in table 2

In the next segment, the Euphrates River exhibits new sudden change in sinuosity and river morphology from sinuous to meandering pattern especially in window size 3, $4 \mathrm{Km}$. These changes in sinuosity values are corresponding with West-Qurna subsurface structure. It exhibits increasing in its value downstream of the uplift axis and decreased upstream of uplift axis (Ouchi, 1985). This result is verified clearly in the window size 3 or $4 \mathrm{~km}$ (Fig. 4), where the sinuosity value approached between (1.6-1.4) respectively, whereas the two sides approximately between (1.06-1.3) which it was showed sinuous planform. The subsurface structural map in this area revealed a subsidence represented by a saddle in West-Qurna Field (Fig.5). The next segments of Euphrates River continued in straight pattern toward its crosses with Tigris River near Qurna city (Fig. 5).

\section{Structural Geology Analysis Results}

The results of the geometric analysis for the physical elements of West Qurna Oilfield (Fold facing, Fold orientation, Fold shape in profile plane) used in genetic analysis to understand the structural 
picture for the field. The current study proposes a scenario for West Qurna Oilfield, which is at Cretaceous period the tectonic activity is prevailed with the result of abduction between Arabian and Iranian plateaus, which led to reactivate the basement faults, and induced salt structure below the study area and made uplift then arching, and thinning features. A shallow saddle occurs inside West Qurna Oilfield and the change of Euphrates River route associated with it. The contour maps (fig. 3) referred to that the there is no saddle between West Qurna Oilfield and North Rumaila Oilfield.

\section{CONCLUSIONS}

1. Euphrates River displayed three types of planform channel (Straight, Sinous, and Meandering). These three types emphasized the neotectonic movements on the Mesopotamian basin in general and studied area.

2. The multiple window size of sinuosity is more valuable tool for detection the tectonic effects on the rivers, especially when it detects same morphological change in all window sizes.

3. West Qurna Oilfield is an anticline, upright, non-plunge, asymmetrical, gentle fold.

4. The thickness variation of West Qurna Oilfield, when the crest is thinner than its limbs may attribute to bending force due to salt structure force.

5. Three combined main forces create West Qurna Oilfield. These are tectonic movements, reactivated basement faults, and Hormuz salt.

6. The general fold axis direction of West Qurna Oilfield is N-S with little inclination toward NW$\mathrm{SE}$ with $\left(2^{\circ}\right.$ to $\left.4^{\circ}\right)$. This inclination may relate to counterclockwise rotation of the Arabian plate and this direction compatible with surrounding fold axes fields of southern Iraq.

\section{REFERENCES}

Adams, J. 1980. Active Tilting of the United States Mid Continent: Geodetic and Geomorphic Evidence. Geology, 8 (9): 442-46.

Al-Khadhimi, J. A. M., Sissakian, V. K., Fattah, A. S., and Dikran, D. B., 1996. Tectonic Map of Iraq. Baghdad.

Al-Sakini, J., 1986. Neotectonic Activity in Basrah vicinity and the dryness of Western Canals of Shatt Al-Arab., in Proceedings of the first symposium on Khor Al-Zubair. Marine Science Center, Basrah University, 415-416.

Al-Sakini, J., 1993. New Window on the Mesopotamian History in the Light of Geological Evidences and Archaeology. Dar Al-Shuaon AlThakafiya Al-Aamah, Baghdad, (in Arabic).

Aswathy, M.V., Vijith, H., and Satheesh, R., 2008. Factors influencing the sinuosity of Pannagon River, Kottayam, Kerala, India: An assessment using remote sensing and GIS. Environmental Monitoring and Assessment., 138:173-180.

Bhattacharya, A. R., 2005. A classification of folds: role of axial angle and thickness ratio. Geoinformatics, 16(1): 2734.

Brice, J., 1984. Meandering pattern of the White River in Indiana an analysis in Fluvial geomorphology, edited by M. O. Morisawa. Binghamton, NY: State University of New York Press, 178-200. 
Buday, T. and S. Z., Jassim., 1987. The Regional eology of Iraq, Vol.2, Tectonism Magmatismand Metamorphism. edited by I. I. Kassab and M. J. Abbas. Baghdad.

Burnett, A. W., Schumm, S. A., 1983. Alluvial river response to notectonic deformation in Louisiana and Mississippi, Science, 222 (4619): 49-50.

Ebisemiju, F. S., 1994. The sinuosity of alluvial river channels in the seasonally wet tropical environment: case study of River Elemi, Southwestern Nigeria. Catena, 21 (1):13-25.

Fleuty, N.J., 1964. The description of folds. Proceeding of Geologists Association, 75(4):461-92.

Fossen, H., 2016. Structural Geology. 2nd ed. Cambridge University Press.

Gasparini, N. M., 2016. Personal Communication.

Grabowski, J.J., 2014. Petroleum system of the Tethyan region: AAPG Memoir, 106: 379-467.

Groshong, R.H., 2006. 3-D Structural Geology: A Practical Guide to Quantitative Surface and Subsurface Map Interpretation. 2nd ed.

Holbrook, J., and Schumm S. A., 1999. Geomorphic and sedimentary response of rivers to tectonic deformation: A brief review and critique of a tool for recognizing subtle epeirogenic deformation in modern and ancient settings. Tectonophysics, 305(1-3): 287-306.

Jassim, S. Z., and Goff, J. C., 2006. Geology of Iraq. Dolin, Prague and Moravian Museum, 439 pp.

Japan Aerospace Exploration Agency Earth Observation Research Center (JAXA -EORC). Accessed on 16 June 2018.

Karim, H. H.,1989. Qualitative interpretation of Basrah aeromagnetic Map, SE Iraq. Journal of Geological Society Iraq, 22(8).

Karim, H. H., 1993. General properties and patterns of the gravity field of Basrah Area. Geological Journal, 26(1): 154-167.

Karim, H.H., Ali, H.Z., and Hamdullah, A.H., 2010. Digitally processed geophysical data sets for identification of geological features in Southern Iraq. Engineering and Technology Journal, 28(2): 236-252.

Langbein, W.B., Leopold, L.B., 1966. River meanders -theory of minimum variance. physiographic and hydraulic studies of rivers. Geological Survey Professional Paper, 422-H:1-15.

Lazim, A.A., 2011. A Structural Study of Nahr Umr Structure-Southern Iraq. Unpublished MSc. Thesis, University of Baghdad.

Leopold, L.B., and Wolman, M.G., 1957. River channel patterns: braided, meandering, and straight. USGS Professional Paper, 282-B: 51.

Mueller, J.E., 1968. An introduction to the hydraulic and topographic sinuosity indexes. Annals of the Association of American Geographers, 58(2): 371-85.

Numan, M.S., 1997. A plate tectonic scenario for the Phanerozoic succession in Iraq. Journal of the Geological Society of Iraq, 30(2): 85-110.

Numan, M.S., 2000. Major Cretaceous tectonic events in Iraq. Rafidain Journal of Science, 11(3): 32-52.

Ouchi, S., 1985. Response of alluvial rivers to slow active tectonic movement. Geological Society of America Bulletin, 96(4): p504-15.

Petrovszki, J., and Gábor, T., 2010. Channel sinuosity of the Körös River system, Hungary/Romania, as possible indicator of the neotectonic activity. Geomorphology, 122 (3-4): 223-30.

Van der Pluijm, B. A., and Marshak, S., 2004. Earth Structure an Introduction to Structural Geology and Tectonics. 2nd ed. McGraw-Hill. 672 pp.

Schumm, S. A., 1963. Sinuosity of alluvial rivers on the great plains. Bulletin of the Geological Society of America, 74 (9): 1089-1100.

Schumm, S.A., and Khan, H.R., 1972. Experimental study of channel patterns. Bulletin of the Geological Society of America, 83(6): 1755-70.

Schumm, S.A., 1986. Alluvial river response to active tectonics, studies in geophysics active tectonics: National Academy Press, Washington D.C., 80-94.

Schumm, S.A., Dumont, J. F., and Holbrook J.M., 2002. Active Tectonics and Alluvial Rivers. Cambridge University Press. 292 pp.

U.S. Geological Survey, 2018. EarthExplorer, accessed on 16 June 2018. 
Timár, G., 2003. Controls on channel sinuosity changes: A case study of the Tisza River, the great Hungarian Plain. Quaternary Science Reviews, 22 (20): 2199-2207.

Yacoub, S.Y., 1992. The Geology of AlBasrah, Abadan \& Bubian Quadrangles, Sheets NH-38-8, NH-39-5 \& NH-399. Series of Geological Maps, Scale 1: 250000.Int. Rep. GEOSURV.

Yacoub, S.Y., 2011. Stratigraphy of the Mesopotamian Plain. Iraqi Bulletin of Geology and Mining, Issu. (Special Issue) 4:47-82.

Zámolyi, A., Székely, B., Draganits, E., and Timár, G., 2010. Neotectonic control on river sinuosity at the Western margin of the Little Hungarian Plain. Geomorphology, 122(3-4): 231-43. 